\title{
EXPLORING THE MYTHICAL INNER LIFE OF A BROKEN METROPOLIS: A COMPARISON OF GYAN PRAKASH'S MUMBAI FABLES AND JEET THAYIL'S NARCOPOLIS
}

\author{
Rincy Philip ${ }^{{ }^{*} \text {, Dr. V.S. Bindhu }}{ }^{2}$ \\ ${ }^{1}$ Research Scholar, Department of English, Noorul Islam Centre for Higher Education, \\ Kanyakumari (Dist), Tamil Nadu, India. \\ ${ }^{2}$ Assistant Professor, Department of English,Noorul Islam Centre for Higher Education, \\ Kanyakumari (Dist), Tamil Nadu, India.
}

\section{ABSTRACT}

Jeet Thayil is a versatile figure in Indian Literature whose contributions to world literature includes many poems, novels and music. His song collection include Gemini (1992), Apocalypso (1997), English (2004), These Errors Are Correct (2008). He also edited many books, which includes Divided Time: India and the End of Diaspora, The Bloodaxe Book of Contemporary Indian Poets and 60 Indian Poets. He is famous for his first novel Narcopolis, which is set in Mumbai. This work is shortlisted for Man Booker Prize for fiction in 2012.Gyan Prakash is another important figure in modern historic India whose handouts lead India through a focus of wealth and secured life. He is also a professor of history and included as a member of subaltern studies. Prakash's writings mainly focus on problems of post colonialism. His famous work is Mumbai Fables: A History of an Enchanted City. This paper tries to find out the history of Mumbai Metropolis with the comparison study of Jeet Thayil's Narcopolis and Gyan Prakash's Mumbai Fables. Both these works shows the hidden history of Mumbai with its both positive and negative structures.

KEYWORDS: Mumbai Metropolis, Thugs, Smugglers, Narcotics, Brothels, Sex, Opium

Article Received: 18 October 2020, Revised: 3 November 2020, Accepted: 24 December 2020

The paper entitled "Exploring the Mythical Inner Life of a Broken Metropolis: A Comparison of Gyan Prakash's Mumbai Fables and Jeet Thayil's Narcopolis" tries to find out the life and hope in Mumbai Underworld. From this comparative learning, these two works mainly focus on the mythical inner life of Bombay metropolis. Jeet Thayil represent a world, which expresses the hidden history of Bombay through his work Narcopolis. He wrote from his own experiences that when he lived in Mumbai. The place of drugs, violence, mafia dons and rich in many unlawful practices. Narcopolis is a voyage from Bombay city to Mumbai metropolis. His experiences in Bombay underworld as he was addicted to drugs, sex and opium. Jeet Thayil through this single work now considered as versatile figure in the history of English literature. Gyan prakash, another important figure, also an urban historian who is famous through his work Mumbai Fables, expresses a country with new economic stability. His work mainly focusses on Mumbai nights with gossips, politics, terror attacks etc. This outer layer of city is obviously a bright spot for films and movies but mainly its inner layer experiences the life of common people who suffered a lot for daily bread. They are under the control of Mafia dons, smugglers and thugs. The most important fact about Mumbai is the people can earn many from nothing. Many people from all over the country settled in Mumbai and they lead a happy and secured life. On the other side, Mumbai is a capital of unhuman practices. People can lead a better life when they are under the glazing of Mumbai Metropolis. There were many open doors to lead a life with clear facts. Gyan Prakash expresses these clearly. People lived in Mumbai has many parameters. They are classify as poor, average and above average categories. Both these writers point out the condition of Mumbai from old age to new. They express their own experiences through these two works Narcopolis and Mumbai Fables.

Jeet Thayil through his work Narcopolis tries to illustrate the history of humans who were the permanent residents living in Bombay. This novel representing social political and economic background of a metropolitan city. Narcopolis narrates the story of 
Bombay, which is now Mumbai. As the name changes, life and situation also changes accordingly. However, the fact is that, common people or slum dwellers always lead an unhealthy and unhappy life situation. They do not matter if the name or status of city changes or not. Once they are addicted to world of drugs and smugglers the consolation is not easy from the mythical inner life to lead a healthy and secured life. Here he represents a group of people with lot of struggle, frustration and pain. It is another form of life addiction to narcotic world with sex, drugs and alcohol. The main plot of the story focusses on a character called Dimple. She is a beautiful, elegant and young girl. A painter named Newton Xavier sexually misuses her. The story moves on through the life of a street named Shuklaj Street. The whole street is crowded with many brothels, opium and alcohol, which gave a way for drug addiction, prostitution and grown up criminals. According to the words of Jeet Thayil, Bombay is a place, which depicts a non shining and unlawful India. In the novel, the character Rashid said: "He could see it on the faces and smell it on the air, cocaine and MOMA and Ecstasy, new drugs for new Bombay."(281). Narcopolis depicting another side of Mumbai with no shining life happiness. Most people are suffering with poverty, sick, unhappy marriages, uneducated children etc. On the other side, out of 12 million people, 6 million lead a healthy and secured life while 6 million are in reverse condition.

While connecting with Gyan prakash's Mumbai Fables, it describes a shaped city with many industrial pressures. Prakash detailing about a nation with many optimistic attitudes towards a broken metropolis. It is very much inspirational for literary and cinematic fields. Many architectural and artistic glamour mould the city with a contrasting background. Gyan Prakash is not trying to represent a city with its flaws but on the positive side, he tries to convey only the best part of the city with all its effectiveness. $\mathrm{He}$ tries to portray the historical aspects about the metropolitan city with its aim is not to explore the hidden that effect the new generation an awkward. He maintains to convey facts from fiction. Many people inside and outside India lead their daily bread from the income that saved from the better side of Mumbai. Mumbai has its own culture and history. Gyan prakash tries to convey only the history not to ruin the city by showing its only harsh life situations and hidden images. He tries to reveal many stories that behind the growth of Mumbai.

Gyan Prakash named his book as Mumbai Fables: A History of an Enchanted City. From this title, he conveys all the beauties of Mumbai metropolis as not trying to convey its pessimistic effects. The book enriched commonly with the history that lead the whole country. While depicting about the Metropolis he uses India as a main factor. This is because the history of India can only be completing by saying about the history of this Metropolitan city. By his book, he reveals a voyage through the city, which provides many realistic stories that moulded with authentic life happenings. He focusses only on the permanent residents or natives about Mumbai, which then evaluates about nationalism among natives and the colonialism. Bombay is not only a city or Metropolis; it is a place where life exists. People living with rich Indian culture and histories. As from Mumbai Fables, Mumbai is a city with full of tremendous opportunities and poor from any part of the world can gave rise and lead a secured healthy life. Prakash's writings are not connected with contemporary issues such as terrorist attacks, natural hazards etc. He sprightly goes through the sixteenth century to reveal the story behind Mumbai's historic background.

Narcopolis explores and totally neglecting all the positive aspects of a metropolitan city. Novel consist of fully pathos and the people lived there has a special and separate story. On the other way the novel has an autobiographical tone that reveals his own life problems that depicted by Jeet Thayil. It is a perfect part in the form of literature that is shows the reflection of life. All the characters in the novel has their own mental struggles. They have their own choices.

"Yes, why not? Put our shame on display, so people understand the lowest of the low, prostitutes and criminals and drug addicts, people with no faith in God or man, no faith in anything expect the truth of their own senses." (Narcopolis, 288)

This simple word reveals all the mental problems or struggles that lead a life in Mumbai slums. The fact is that these characters are not leading a secured life. They are always living in slums and streets. They move their life by prostitution or robbery. In addition, 
they never have a regret in their life. They all are living in the shadow falling side of Mumbai, which means they all are in darker side. As in daily newspaper, report gave a clear evidence about the Mumbai drug mafia and their daily reports. More than 10 cases reported daily in every newspaper in Mumbai. The fact is that most of these are robbery cases and women who lived in low living standards hold these. These are the part of certain organised crimes, which was active in the highest area of metropolis. Within a time several mafia dons and thugs have dominated Mumbai metropolis. Jeet Thayil gave a clear report of all these facts through his work Narcopolis. While comparing an also contrasting with Mumbai Fables Mumbai has its own problems as per the positive and negative sides. Gyan Prakash concept of Mumbai with vast with polished and secured life. All the way these two works explore two different categories of Mumbai slum life. Metropolitan Mumbai is absolutely a safe city. The major problem is that it has a crime-filled underworld. With organized crime, smuggling, black markets, and kidnapping the rich for vast ransoms.

\section{REFERRENCES}

1. Booker, M. K. (1994). Dystopian literature: A theory and guide. Westport: Greenwood Press.

2. Boo, Katherine. (2014). Behind the Beautiful Forevers: Life, Death and Hope in a Mumbai Undercity. India: Random House.

3. Falerio,Sonia. (2015). Beautiful Thing: Inside the secret world of Bombay's dance bars. India: READ HOW YOU WANT COM LTD.

4. Prakash, G. (2010). Mumbai fables. Princeton: Princeton University Press.

5. Thayil, Jeet, (2013). Narcopolis. Faber and Faber. 